\title{
Komemoriranje srednjovjekovnih hrvatskih vladara u hodonimima Hercegovine
}

DiJana Korać

Sveučilište u Mostaru

Filozofski fakultet

E-pošta: dijana.korac@ff.sum.ba

Marina Beus

Sveučilište u Mostaru

Filozofski fakultet

E-pošta: marina.beus@ff.sum.ba
UDK: 766(497.6 Hercegovina)

911.375(497.6 Hercegovina)

Prethodno priopćenje

Primljeno: 3. svibnja 2020.

Prihvaćeno: 10. lipnja 2020.

\section{Sažetak}

$\mathrm{U}$ radu se analizira prisutnost srednjovjekovnih hrvatskih vladara u nazivlju trgova i ulica na području dvije hercegovačke županije (Hercegovačko-neretvanska i Zapadno-hercegovačka). Analiza uličnoga nazivlja na području Hercegovine pokazala je kako su srednjovjekovni hrvatski vladari zastupljeni u gradovima i općinama s većinski hrvatskim stanovništvom. Usporedbom dobivenih podataka s rezultatima do kojih se došlo sličnim istraživanjem u Republici Hrvatskoj uočavaju se velike sličnosti.

Ključne riječi: srednjovjekovni hrvatski vladari; Hercegovina; hodonimi; ulice; trgovi. 
Dijana Korać - Marina Beus - Komemoriranje srednjovjekovnih hrvatskih vladara...

\section{Uvod}

Tematika (pre)imenovanja ulica i trgova posljednjih je desetljeća predmet interesa interdisciplinarnih i multidisciplinarnih istraživanja, što je evidentno i na primjeru hrvatske znanstvene zajednice $\mathrm{u}$ čijem je krugu nastao prilično velik broj radova vezanih uz ovu tematiku. Taj je interes posebno vezan uz razdoblje nakon 90-ih godina prošloga stoljeća, odnosno nakon sloma komunizma i dolaska demokratski izabrane vlasti. ${ }^{1}$ Nazivlje ulica i trgova u uskoj je svezi s društveno-političkim okolnostima, pa se svaka velika društveno-povijesna promjena manifestira i na izmjeni ulične nomenklature što je evidentno i na primjeru Hercegovine, koja je tijekom 20. stoljeća bila u sastavu različitih država, a ulična se onomastika mijenjala svaki put prilikom nekoliko promjena različitih vlasti. Predmet ovoga rada jest razdoblje nakon raspada socijalističke Jugoslavije, odnosno nastanka samostalne republike Bosne i Hercegovine kada dolazi do posljednje značajne promjene naziva različitih institucija te ulica i trgova. Tada na prijedlog novoformiranih Povjerenstava za imenovanje ulica i trgova u uličnoj nomenklaturi dolazi do odbacivanja simbola i osoba koji podsjećaju na ranije razdoblje - socijalizma, odnosno na ondašnje zadane postavke "bratstva i jedinstva", pa su imena ranijih "revolucionara" te različitih političara i osoba zaslužnih u društvenoj

1 Ovdje navodimo neke od tih radova: Borislav Grgin, "Primjer selektivnog pamćenja: hrvatski srednjovjekovni vladari u nazivlju ulica i trgova najvažnijih hrvatskih gradova", u: Povijesni prilozi, 32, Zagreb, 2007., str. 283-295; Zlatko BEgonja, "Odonimi kao ideološke manifestacije na primjeru Zadra u XX. stoljeću", u: Radovi Zavoda za povijesne znanosti HAZU u Zadru, 48, Zadar, 2006., str. 703-720; ZDRAVKa JELASKa MARIJAN, "Službena imenovanja i preimenovanja ulica u Splitu 1912.-1928. godine", u: Studia ethnologica Croatica, 26, Zagreb, 2014., str. 229-252; IVANA CrLJENKo, "Izraženost identiteta u gradskoj toponimiji kvarnerskih i istarskih gradova", u: Hrvatski geografski glasnik, Zagreb, 1/2008., str. 67-89; Jelena StAnić - LAURA ŠAKAJA - LANA Slavu, "Preimenovanja zagrebačkih ulica i trgova", u: Migracijske i etničke teme, Zagreb, 1-2/2009., str. 89-124; LenA MirošEvić, "Imena ulica i trgova kao odraz zajedničkoga kulturno-povijesnog naslijeđa", u: Kartografija $i$ geoinformacije, 16, Zagreb, 2011., str. 57-71; BojAn MarJanović, "Promjena vlasti, promjena ulica", u: Diskrepancija, 12, Zagreb, 2007., str. 105-127; LENA MirošEvić - MARIN Borzić, "Ulična nomenklatura grada Splita kao odraz političkih i kulturnih promjena", u: Etnološka tribina: Godišnjak Hrvatskog etnološkog društva, 37, Zagreb, 2014., str. 187-201; IviCA MataIJA, "Gospićka hodonimija", u: Folia onomastica Croatica, 23, Zagreb, 2014., str. 143-158. U navedenim radovima može se vidjeti pregled stranih autora i njihovih djela koji donose rezultate istraživanja ove tematike u različitim zemljama. 
i političkoj zbilji onodobne države zamijenjena novim imenima iz hrvatske povijesti kojima se nastojalo utjecati na jačanje nacionalne svijesti, a među kojima su i srednjovjekovni hrvatski vladari. Iako je, uglavnom, prva asocijacija na imena ulica i trgova lakša orijentacija ljudi u određenu prostoru, jasno je da hodonimi imaju puno dublje simboličko značenje i da su, ovisno o određenim okolnostima, odraz političkih opcija te ideoloških koncepcija. Nazivi ulica nose određenu poruku, te "pričaju povijest" kakvu službena vlast "pamti", pa se stoga i na ovaj način zaslužnim ljudima odaje priznanje te zajednici daje primjer "idealnoga ponašanja", koje je u skladu s odgovarajućom političkom orijentacijom. Ako imamo na umu značenje kulturnopovijesnoga nasljeđa u jačanju kolektivnoga identiteta, kao i važnost povijesti i kolektivnoga sjećanja, pri čemu treba imati na umu da se gotovo uvijek radi o selektivnom sjećanju, onda se pri tome može prepoznati i određena uloga ulične nomenklature u oblikovanju kolektivnoga identiteta. ${ }^{2} \mathrm{~S}$ obzirom na navedeno, analiza prisutnosti nacionalnih hodonima vezanih uza srednjovjekovne hrvatske vladare $\mathrm{u}$ najnovijoj uličnoj nomenklaturi na području Hercegovine, svakako ukazuje na jedan segment kolektivnoga, odnosno selektivnoga sjećanja Hrvata koji žive na ovome području. Naime, ulična onomastika u drugim hercegovačkim gradovima i općinama znatno je drugačija zbog manje zastupljenosti Hrvata, pa su stoga bile i manje izmjene u uličnom nazivlju u odnosu na raniji društveno-politički sustav. Valja

2 Duško Petrović, "Anatomija identiteta. Teorijsko problematiziranje identiteta", u: Etnološka istraživanja, 11, Zagreb, 2006., str. 226-227; I. CRLJENKO, "Izraženost identiteta u gradskoj toponimiji kvarnerskih i istarskih gradova", str. 69; L. MirošEvić, "Imena ulica i trgova kao odraz zajedničkoga kulturno-povijesnog naslijeđa", str. 69; Lena MirošEvić, "Gradska toponimija kao nositelj kolektivnih identiteta", u: Vladimir Skračić - Josip FARIČIĆ (ur.), Geografska imena. Zbornik radova s Prvog nacionalnog znanstvenog savjetovanja o geografskim imenima, Zadar, 2011., str. 83-93; J. STANIĆ - L. ŠAKAJA - L. Slavuj, "Preimenovanja zagrebačkih ulica i trgova", str. 90; B. MarJanović, "Promjena vlasti, promjena ulica", str. 109; B. GrGIN, "Primjer selektivnog pamćenja: hrvatski srednjovjekovni vladari u nazivlju ulica i trgova najvažnijih hrvatskih gradova", str. 283-295; Z. BEgonjA, "Odonimi kao ideološke manifestacije na primjeru Zadra u XX. stoljeću", str. 719; Eric HobsBawm, "Izmišljanje tradicije", u: Maja Brkljačić - SAndra Prlenda (ur.), Kultura pamćenja $i$ historija, Zagreb, 2006., str. 139. Više relevantnih radova vezanih uz tematiku kolektivnoga sjećanja i pamćenja vidjeti u zbornicima radova: M. Brkljačić - S. Prlenda (ur.), Kultura pamćenja i historija, Zagreb, 2006; Michal Sladeček - Jelena Vasiljević - Tamara Petrović, Kolektivno sećanje i politike pamćenja, Beograd, 2015. 
Dijana Korać - Marina Beus - Komemoriranje srednjovjekovnih hrvatskih vladara...

konstatirati da je na ovakve izmjene hodonima zasigurno utjecala i nacionalna svijest koja se prema različitim istraživanjima posebno ističe nakon ratova kada dolazi do jačanja zajedničkoga identiteta. ${ }^{3}$

Analiza obuhvaća dvije "hercegovačke" županije (Hercegovačko-neretvanska i Zapadno-hercegovačka), koje čini 13 hercegovačkih gradova i općina (Mostar, Čapljina, Široki Brijeg, Ljubuški, Čitluk, Stolac, Ravno, Neum, Grude, Posušje, Prozor-Rama, Jablanica i Konjic). No, odmah treba naglasiti da ovi hodonimi nisu prisutni u Jablanici i Konjicu (u kojima Hrvati nisu zastupljeni u većem broju) te u najmanjoj hercegovačkoj općini Ravno, ${ }^{4} \mathrm{pa}$ će analiza biti donesena na temelju podataka vezanih uz ostalih 10 hercegovačkih gradova i općina. Analiza se temelji na podatcima iz službenih glasila te web stranica gradova i općina. ${ }^{5}$ Dobiveni podatci o učestalosti pojave srednjovjekovnih hrvatskih vladara u imenima ulica i trgova navedenih gradova i općina uspoređuju se s rezultatima do kojih se došlo sličnim istraživanjem u Republici Hrvatskoj. ${ }^{6}$

3 O tome: BORIS BANOvAC, "Etničnost i regionalizam u Istri: povijesni rakurs i suvremeni kontekst", u: Migracijske teme, Zagreb, 4/1996., str. 279; Boris BANOVAC, "Modernitet, prostor i konstrukcija identiteta", Revija za sociologiju, Zagreb, 3-4/2000., str. 114; DušKo SEkulić, "Prostor i identitet", u: Erasmus - časopis za kulturu demokracije, 19, Zagreb, 1997., str. 46-57.

4 Valja kazati kako je riječ o vrlo maloj općini i naselju u kojemu postoji samo Trg Ruđera Boškovića (na toj su adresi sve općinske institucije).

5 Rezultati ovoga istraživanja (izneseni u tekstu, tabelama i grafikonima) temelje se na analizi podataka objavljenima u: Službeno glasilo Općinskog vijeća općine Čitluk, Čitluk, 8/2013., str. 140-141; Službeno glasilo Općinskog vijeća općine Čitluk, Čitluk, 5/2015., str. 85-87; Narodni list općine Čapljina. Službeno glasilo, Čapljina, 2/2016.; Službeni glasnik općine Posušje, Posušje, 1/2005., str. 1-8; Službeni glasnik općine Široki Brijeg, Siroki Brijeg, 1/2004.; Službeni glasnik općine Ljubuški, Ljubuški, 1/2016.; Narodni list općine Stolac, Stolac, 3/1994., str. 2-3; Narodni list općine Neum, Neum, 1/1993., str. 3-4; Rješenje o utvrđivanju novih imena ulica u Neumu, br. Rješenja R-01-I-13/02, Neum, 27. 3. 2002.; Odluka o adresnom sustavu općine Neum i označavanju naseljenih mjesta, ulica i trgova nazivima te zgrada brojevima, broj Odluke 01-02-870/17, Neum, 19. 6. 2017.; Odluka o obilježavanju ulica, parka i trga imenima i zgrada brojevima na području općine Grude, br. Odluke 01-23-250/04, Grude, 22. lipnja 2004.; Službeno glasilo Općinskog vijeća općine Mostar, Mostar, 1-2/1995., str. 10; Službeno glasilo Općinskog vijeća općine Mostar, Mostar, 5/1995., str. 16; Službeno glasilo općina Zapad, Jugozapad i Jug Mostar, Mostar, 3/1998., str. 11; https://prozor-rama.org/o-opcini (27. 4. 2020.); https://mapeulica.com/ mapa-prozor-bih-3192279 (27. 4. 2020.).

6 B. Grgin, "Primjer selektivnog pamćenja: hrvatski srednjovjekovni vladari u nazivlju ulica i trgova najvažnijih hrvatskih gradova", str. 283-295. 


\section{Rezultati istraživanja}

Kako je spomenuto, u nazivlju ulica i trgova deset hercegovačkih gradova i općina (Mostar, Čapljina, Široki Brijeg, Ljubuški, Čitluk, Stolac, Neum, Grude, Posušje i Prozor-Rama) evidentna je zastupljenost srednjovjekovnih hrvatskih vladara. Naime, u ovim hercegovačkim gradovima i općinama nalazimo ukupno 46 ulica i jedan trg koji komemoriraju srednjovjekovne hrvatske vladare (ukupno 14 vladara).

Što se tiče geografske distribucije uličnoga nazivlja, zanimljivo je da se na prvome mjestu ne nalazi najveći hercegovački grad - Mostar, nego najveći broj ovih ulica u Hercegovini ima Posušje u kojemu 12 ulica $(25,5 \%)$ nosi ime po nekom srednjovjekovnom hrvatskom vladaru. Slijedi Široki Brijeg u kojemu nalazimo 11 ovakvih hodonima, odnosno 23,4\% od ukupna broja u Hercegovini. Na trećem mjestu po učestalosti pojavljivanja imena srednjovjekovnih hrvatskih vladara u nazivlju ulica i trgova nalazi se Mostar s 9 ulica (19,1\%). Sljedeće mjesto zauzima grad Čapljina u kojemu tri ulice nose ime nekoga hrvatskog srednjovjekovnog vladara, te jedan od tri gradska trga, što čini $8,5 \%$ od ukupna broja imenovanih ulica i trgova. U ostalim je gradovima i općinama učestalost pojavljivanja srednjovjekovnih hrvatskih vladara manja, ali je riječ i o mnogo manjim mjestima. U općini Čitluk komemorirano je samo ime jednoga srednjovjekovnoga hrvatskog vladara (kralja Tomislava) ali u tri naseljena mjesta ove općine, ${ }^{7}$ što je $6,4 \%$ ukupna broja imenovanih ulica. U Stocu i Neumu nalazimo po dvije ulice (po 4,3\%), a u Grudama i općini Prozor-Rama po jednu ulicu nazvanu po srednjovjekovnome hrvatskom vladaru (po 2,1\%). Napominjemo da smo u analizi o zastupljenosti broja ulica po pojedinim gradovima i općinama uračunali i dvije ulice u Ljubuškom - Ulica hrvatskih knezova i Ulica hrvatskih kraljeva (4,3\% od ukupna broja). ${ }^{8}$ Smatramo važnim napomenuti da je Ljubuški prije 2016. godine, kada je donesena posljednja Odluka o određivanju naziva trgova i ulica, imao tri ulice nazvane po srednjovjekovnim hrvatskim vladarima

7 Ulice kralja Tomislava nalaze se u Čitluku, Potpolju i Bijakovićima.

8 Riječ je o ulicama iz najnovije Odluke o imenovanju ulica i trgova koja je donesena početkom 2016. godine. Službeni glasnik općine Ljubuški, Ljubuški, 1/2016., str. 3-4. 
Dijana Korać - Marina Beus - Komemoriranje srednjovjekovnih hrvatskih vladara...

(Trpimir, Petar Krešimir IV. i Zvonimir) te jedan trg (kralja Tomislava), ${ }^{9}$ a ovom posljednjom Odlukom imenovane su dvije nove ulice koje komemoriraju zajedno sve hrvatske knezove i kraljeve.

\begin{tabular}{|l|l|l|}
\hline Grad/općina & Ukupan broj & Ime vladara \\
\hline Posušje & 12 & $\begin{array}{l}\text { Ljudevit Posavski, Višeslav, Mislav, Trpi- } \\
\text { mir, Domagoj, Branimir, Tomislav, Petar } \\
\text { Krešimir IV., Zvonimir, Petar Svačić, Ma- } \\
\text { tija Korvin, kraljica Jelena }\end{array}$ \\
\hline Široki Brijeg & 11 & $\begin{array}{l}\text { Mislav, Trpimir, Domagoj, Zdeslav, Bra- } \\
\text { nimir, Tomislav, Stjepan Držislav, Petar } \\
\text { Krešimir IV., Zvonimir, Petar Svačić, kra- } \\
\text { ljica Jelena }\end{array}$ \\
\hline Mostar & 9 & $\begin{array}{l}\text { Višeslav, Mislav, Trpimir, Domagoj, Bra- } \\
\text { nimir, Tomislav, Petar Krešimir IV., Zvo- } \\
\text { nimir, kraljica Jelena }\end{array}$ \\
\hline Čapljina & 4 & $\begin{array}{l}\text { Domagoj, Tomislav (trg), Petar Krešimir } \\
\text { IV., Zvonimir }\end{array}$ \\
\hline Čitluk & 3 & Tomislav \\
\hline Ljubuški & 2 & hrvatski kraljevi i hrvatski knezovi \\
\hline Neum & 2 & Domagoj, Tomislav \\
\hline Stolac & 2 & Domagoj, Tomislav \\
\hline Grude & 1 & Tomislav \\
\hline Prozor-Rama & 1 & Tomislav \\
\hline
\end{tabular}

Tabela 1. Zastupljenost ulica i trgova s imenima srednjovjekovnih hrvatskih vladara po gradovima i općinama

9 Nazivi prijašnjih ulica mogu se i danas naći na nekim web stranicama, npr. http://www.kartabih.com/karta-ljubuski/ (27. 4. 2020.). 


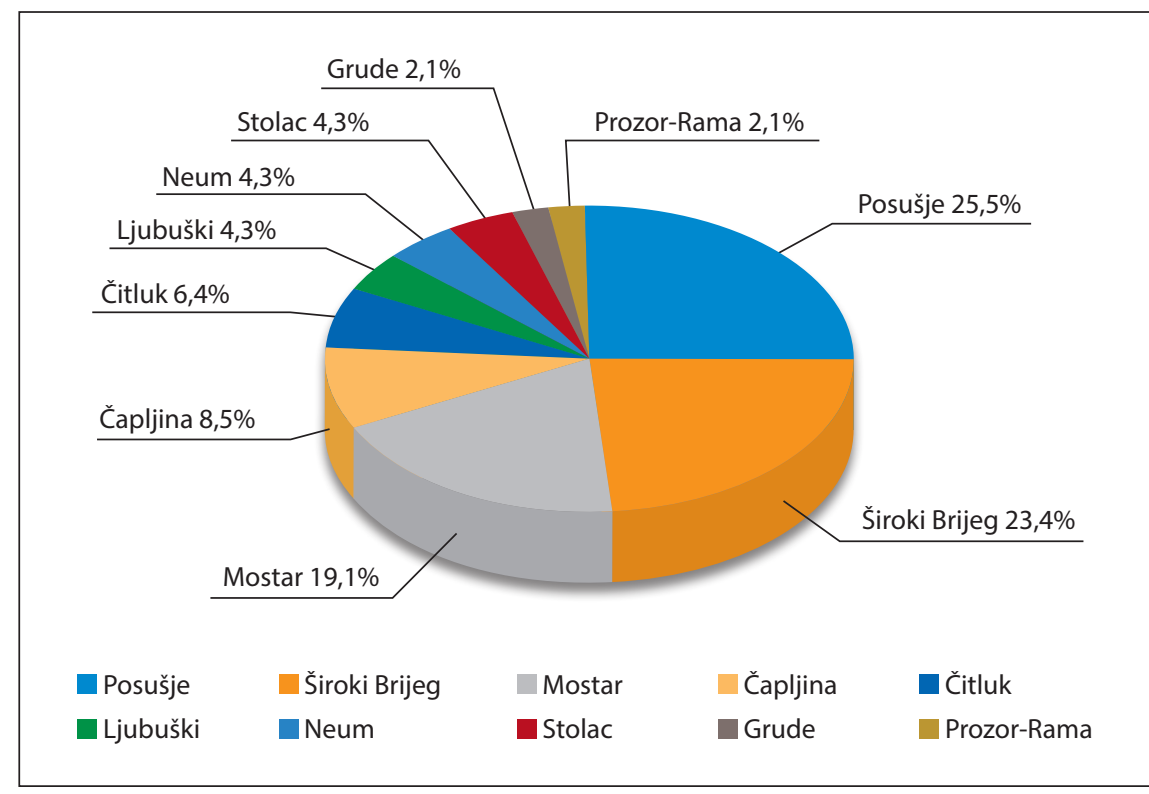

Grafikon 1. Zastupljenost ulica i trgova s nazivima srednjovjekovnih hrvatskih vladara po gradovima i općinama

Analiza zastupljenosti imena ${ }^{10}$ srednjovjekovnih hrvatskih vladara u nazivima hercegovačkih ulica i trgova dala je sljedeće rezultate. Najprije valja kazati da su hrvatski kraljevi zastupljeniji od knezova. S druge pak strane uočava se da $55,6 \%$ ovih hodonima (25 od 45 ulica i trgova) nosi ime po ranosrednjovjekovnom kralju (Tomislav, Petar Krešimir IV., Dmitar Zvonimir, Petar Snačić, Stjepan Držislav i kraljica Jelena), dok je samo jedan ugarsko-hrvatski kralj komemoriran u hercegovačkim ulicama a riječ je o Matiji Korvinu (1 ulica, odnosno 2,2\%). Knezovima iz hrvatske narodne dinastije posvećeno je ukupno 16 ulica (35,6\%), među kojima prednjači Domagoj sa šest ulica, a zatim slijede Mislav, Trpimir i Branimir s po tri ulice, dok je Zdeslavu posvećena samo jedna ulica. Na kraju, u hercegovačkim ulicama komemorirana su i imena kneza Višeslava (2 ulice) te Ljudevita Posavskog s jednom ulicom.

Analiza distribucije pojedinoga hrvatskog vladara u uličnoj nomenklaturi dala je sljedeće rezultate. Očekivano, najzastupljeniji je kralj

$10 \mathrm{U}$ analizi zastupljenosti imena srednjovjekovnih hrvatskih vladara u nazivlju hercegovačkih ulica ne uzimamo u obzir dvije navedene ulice u Ljubuškom koje su posvećene svim hrvatskim knezovima i kraljevima. 
Tomislav (910.-928.) kojega u nazivlju ulica i trgova komemorira ukupno devet hercegovačkih gradova i općina (u kojima njegovo ime nosi jedan trg i 10 ulica), što čini $24,5 \%$ od ukupno zabilježenih ulica i trgova koji nose imena po srednjovjekovnim hrvatskim vladarima. ${ }^{11}$ Činjenice da trgovi kao najreprezentativniji dijelovi grada nose imena po "najznačajnijim" ličnostima iz nacionalne povijesti, da je u Hercegovini samo jedan trg posvećen hrvatskom narodnom vladaru a riječ je o Tomislavu (trg kralja Tomislava u Čapljini) te da od deset analiziranih hercegovačkih gradova i općina ulicu ili trg kralja Tomislava nema samo Ljubuški, gdje u uličnome nazivlju nema pojedinačno imenovanih hrvatskih kraljeva i knezova nego su dvije ulice posvećene svima njima zajedno (Ulica hrvatskih knezova i Ulica hrvatskih kraljeva) ${ }_{,}^{12}$ najbolje govore o mjestu kralja Tomislava u kolektivnom sjećanju Hrvata u Hercegovini. Činjenice da je Tomislav prvi hrvatski kralj kojega je papa oslovio titulom rex, pobjednik u borbama protiv Mađara i Bugara, te jaki hrvatski vladar koji je prema pisanju poznatoga bizantskog cara Konstantina Porfirogeneta (De administrando Imperio) imao 100.000 pješaka, 60.000 konjanika te 80 velikih i 100 manjih brodova, svakako su utjecale na prvo mjesto kralja Tomislava na ovoj ljestvici. ${ }^{13}$ Vrijedi napomenuti da je od svih hrvatskih narodnih vladara kralj Tomislav zauzimao najistaknutije mjesto i u socijalističkoj Jugoslaviji (osim ranije navedenih činjenica, posebno se isticala njegova pomoć Srbima nakon što su Bugari pokorili Rašku, što je posebno evidentno u ondašnjim jugoslavenskim udžbenicima kada su se ciljano apostrofirali pojedini događaji i povijesne ličnosti s

11 Valja napomenuti da ime kralja Tomislava u općini Čitluk nose ulice u tri naseljena mjesta (Čitluk, Potpolje i Bijakovići), dok se jedini trg u Hercegovini posvećen ovome hrvatskom vladaru nalazi u Čapljini.

12 Što se tiče Ljubuškoga, kako je već spomenuto, u ovu su analizu uključeni podatci iz najnovije Odluke o imenovanju ulica i trgova u Ljubuškom (2016.). Naime, nakon dolaska demokratski izabrane vlasti 90-ih godina 20. stoljeća, Ljubuški je u svojim ulicama komemorirao i pojedine srednjovjekovne hrvatske vladare. Među tim vladarima bio je i kralj Tomislav čije je ime nosio jedan trg u Ljubuškom do 2016. godine, te knez Trpimir i kraljevi Petar Krešimir IV. i Dmitar Zvonimir čija su imena nosile ulice do navedene godine.

13 O kralju Tomislavu više: Ivo Goldstein, "O Tomislavu i njegovom dobu", u: Radovi Instituta za hrvatsku povijest, 18, Zagreb, 1985., str. 23-55; NeveN BUDAK, Prva stoljeća Hrvatske, Zagreb, 1994., str. 30-33; ToMislav RaUKAR, Hrvatsko srednjovjekovlje, prostor, ljudi, ideje, Zagreb, 1998., str. 36-39; Fr ANJO ŠAnjek (ur.), Povijest Hrvata, knj. 1, Srednji vijek, Zagreb, 2003., str. 90-92, $145-148$. 
ciljem jačanja "bratstva i jedinstva"). ${ }^{14}$ No, unatoč ovoj činjenici nismo pronašli nijednu ulicu u Hercegovini koja je u vrijeme druge Jugoslavije nosila njegovo ime. S druge pak strane, u vrijeme Kraljevine SHS odnosno Kraljevine Jugoslavije u Mostaru je postojala ulica kralja Tomislava, ${ }^{15}$ a njegovo značenje u toj državi ilustrira organizirano obilježavanje 1000. godišnjice Hrvatskoga kraljevstva. ${ }^{16}$

Drugi po učestalosti pojavljivanja u hercegovačkim hodonimima jest knez Domagoj (864.-876.) sa šest ulica, i to u Mostaru, Posušju, Čapliini, Širokom Brijegu, Stocu i Neumu (13,3\% od ukupna broja). Uspješne borbe s Mlečanima "najgorega kneza Slavena", kako je Domagoja nazvao mletački kroničar Ivan Đakon, kao i njegova obrana hrvatskoga prostora, zasigurno su razlozi zbog kojih je našao svoje mjesto u uličnoj nomenklaturi. ${ }^{17}$ Sljedeće mjesto dijele kraljevi Petar Krešimir IV. (1058.-1074.) i Dmitar Zvonimir (1075.-1089.) čija imena komemoriraju ulice u Mostaru, Širokom Brijegu, Posušju i Čapljini (po 8,9\% od ukupna broja). Činjenice da je Petar Krešimir IV. kralj

14 Usp. B. GrgIN, "Primjer selektivnog pamćenja: hrvatski srednjovjekovni vladari u nazivlju ulica i trgova najvažnijih hrvatskih gradova", str. 286. O recepciji kralja Tomislava u ondašnjim udžbenicima vidi primjerice: Ivo MAKEK, Prošlost i sadašnjost 1. Udžbenik historije za VI razred osnovne škole, Zagreb, 1963., str. 115-117; Emina Omanović, Istorija-Povijest za VI razred osnovne škole, Sarajevo, 1981., str. 35-38 (ćir.); Ivan Božıć, Istorija za VI razred osnovne škole, Sarajevo, 1965., str. 144-145 (ćir.); MARIJA VRBetić, Historija za I razred gimnazije, Zagreb, 1961., str. 328.

15 Ulica kralja Tomislava postojala je u Mostaru do 1945. godine kada je preimenovana u Braće Fejića, a pod tim imenom postoji i danas. O tome: KARLO Drago Miletić, "Prvi brojevi na mostarskim kućama", u: Motrišta, 22, Mostar, 2001., str. 135, bilješka 1 .

$16 \mathrm{O}$ obilježavanju tisućgodišnjice Hrvatskoga kraljevstva do danas je napisano više vrijednih radova, ali ćemo ovdje spomenuti samo neke iz novijega vremena. Zlatko Matijević, "Kralj Tomislav - prvoborac jugoslavenstva. U povodu osamdesete obljetnice obilježavanja tisućgodišnjice hrvatskoga kraljevstva", u: Hrvatska revija, Zagreb, 3/2005., str. 105-111; HrvoJE GračAnIN, "Povijesni identiteti i politički realiteti: proslava tisućugodišnjice Hrvatskog Kraljevstva 1925. godine", u: Marijana Marinović (ur.), Hrvati i manjine u Hrvatskoj: moderni identiteti. Četvrti hrvatski simpozij o nastavi povijesti, Zagreb, 2014., str. 119-138; MARIO JAREB, Kralj Tomislav kroz tisuć godina. Kralj Tomislav izmedu stvarnosti i mita te proslava tisućite obljetnice Hrvatskoga Kraljevstva 1925. godine i njezini odjeci do danas, Zagreb, 2017.

17 O knezu Domagoju: N. Budak, Prva stoljeća Hrvatske, str. 23-24; T. Raukar, Hrvatsko srednjovjekovlje, prostor, ljudi, ideje, str. 40, 42, 140; F. ŠANJEK (ur.), Povijest Hrvata, knj. 1, Srednji vijek, str. 84-85, 124. 
Dijana Korać - Marina Beus - Komemoriranje srednjovjekovnih hrvatskih vladara...

koji je ujedinio hrvatski etnički prostor i vladao snažnom hrvatskom ranosrednjovjekovnom državom s najvećim državnim teritorijem, zasigurno su utjecale na komemoriranje njegova imena u hercegovačkim ulicama. ${ }^{18}$ Što se tiče kralja Zvonimira, valja reći da je za razliku od ranijega vremena, od 90-ih godina 20. stoljeća njegova vladavina dobila pozitivnu ocjenu. Teza o njegovu ubojstvu i proklinjanju Hrvata na samrti odbačena je kao mit koji je nastao s ciljem pojašnjavanja zašto Hrvati u kasnijem razdoblju nisu imali domaće, nego strane vladare. Također, njegova vjernost papi kao i isticanje kako je njegovo savezništvo s papom bilo na dobrobit hrvatske države, doprinijelo je slici Zvonimira kao uspješna i dobra hrvatskoga kralja, koji prema tome ima veliku vrijednost $\mathrm{u}$ nacionalnom identitetu. ${ }^{19}$

Po tri ulice (po 6,7\%) u Hercegovini imaju knezovi Mislav, Trpimir i Branimir te kraljica Jelena (Mostar, Široki Brijeg i Posušje). Ova tri hrvatska kneza također nisu veliko iznenađenje u uličnoj nomenklaturi Hercegovine. Mislav (835.-845.) se spominje kao jedan od najstarijih hrvatskih vladara, prethodnik kneza Trpimira, koji se uspješno odupro Mlečanima. ${ }^{20}$ Jedan od najistaknutijih hrvatskih vladara čiji je velik ugled zasvjedočen u povijesnim vrelima, te osnivač hrvatske narodne dinastije jest knez Trpimir (845.-864.) za čije je vrijeme hrvatska kneževina doživjela svoj prvi vrhunac, i u čijoj se darovnici iz 852. godine prvi put javlja ime Hrvata. ${ }^{21}$ Njegovo je ime svakako u korelaciji s hrvatskim identitetom, što je također slučaj i s knezom Branimirom. Iz vladavine kneza Branimira (879.-892.) sačuvano je više kamenih natpisa od kojih se posebno ističe onaj iz Šopota kod Benkovca na kojemu je, osim imena kneza Branimira, zabilježen i prvi spomen hrvatskoga imena. Osim toga, u hrvatskoj se historiografiji možda najviše apostrofira njegov odnos s papom Ivanom

18 O Petru Krešimiru IV.: N. Budak, Prva stoljeća Hrvatske, str. 41-45; T. RAUKAR, Hrvatsko srednjovjekovlje, prostor, ljudi, ideje, str. 44-49; F. ŠANJEK (ur.), Povijest Hrvata, knj. 1, Srednji vijek, str. 100-105, 158-160.

19 O kralju Dmitru Zvonimiru: N. Budak, Prva stoljeća Hrvatske, str. 46-48, 111-115; T. RAuKar, Hrvatsko srednjovjekovlje, prostor, ljudi, ideje, str. 44-47, 49-55; Ivo Goldstein (ur.), Zvonimir, kralj hrvatski. Zbornik radova, Zagreb, 1997.; F. Šanjek (ur.), Povijest Hrvata, knj. 1, Srednji vijek, str. 103-110.

20 O Mislavu: N. Budak, Prva stoljeća Hrvatske, str. 19-20; F. ŠAnjek (ur.), Povijest Hrvata, knj. 1, Srednji vijek, str. 71.

21 O knezu Trpimiru: N. Budak, Prva stoljeća Hrvatske, str. 20-22, 71-78; T. RAUKAR, Hrvatsko srednjovjekovlje, prostor, ljudi, ideje, str. 28-31, 299-300; F. ŠAnJeK (ur.), Povijest Hrvata, knj. 1, Srednji vijek, str. 72-79. 
VIII. koji 879. godine blagoslivlja Branimira i hrvatski narod što je tumačeno kao "međunarodno priznanje hrvatske države". ${ }^{22} \mathrm{U}$ ulicama Mostara, Širokoga Brijega i Posušja komemorirana je uspomena i na kraljicu Jelenu, ženu kralja Mihajla Krešimira II. i majku kralja Stjepana Držislava. Očuvanost njezina grobnoga natpisa (iz 976. godine) na kojemu piše: "U ovome grobu počiva Jelena slavna [...] koja je za života bila majkom Kraljevstva i zaštitnicom siročadi i udovica ...", te činjenica da je na Otoku u Solinu dala izgraditi crkvu sv. Marije i crkvu sv. Stjepana, u kojoj su pokapani hrvatski kraljevi, ${ }^{23}$ zasigurno je utjecalo na njezino zauzimanje važna mjesta u hrvatskoj nacionalnoj povijesti, pa slijedom toga i u uličnoj onomastici.

Po dvije ulice (po 4,4\%) u Hercegovini imaju Petar Svačić (Snačić) i knez Višeslav. Naime, ulica kralja Petra Svačića (1093.-1097.) nalazi se u Širokom Brijegu i Posušju, a komemoriranje njegova imena u ovim ulicama zasigurno je uvjetovano činjenicama koje govore o njegovoj borbi protiv Mađara u kojoj je izgubio svoj život, kao posljednji hrvatski kralj. ${ }^{24}$ Dvije ulice u Hercegovini (Mostar i Posušje) nose ime

22 O knezu Branimiru: Josıp Lučić, "Crkvene prilike u Hrvatskoj za kneza Branimira", u: Croatica Christiana periodica, 17, Zagreb, 1986., str. 1-16; ŠImE BAtović (ur.), Hrvatska u doba kneza Branimira, Zadar, 2002.; Mirjana Matijević Sokol - Vladimir Sokol, Hrvatska i Nin u doba kneza Branimira, Zagreb, ${ }^{2} 2005$.; N. BUdAK, Prva stoljeća Hrvatske, str. 26-28; T. RAUKAR, Hrvatsko srednjovjekovlje, prostor, ljudi, ideje, str. 32-35, 295-296, 299-300; F. ŠANJEK (ur.), Povijest Hrvata, knj. 1, Srednji vijek, str. 87-88, 113.

23 O kraljici Jeleni: Frane Bulić, "Nadgrobni napis hrvatske kraljice Helene u Solinu", u: Vjesnik Arheološkog muzeja u Zagrebu, vol. 3, br. 1, Zagreb, 1898., str. 19-24; Frane Bulić, "Izvještaj o crkvi sv. Marije i nadgrobnom napisu kraljice Jelene", u: Vjesnik Arheološkog muzeja u Zagrebu, vol. 5, br. 1, Zagreb, 1901., str. 201-227; Franko Oreb, "Odjeci otkrića Jelenina epitafa u Solinu 1898. godine u hrvatskoj javnosti po izvješćima onodobnog tiska", u: Tusculum: časopis za solinske teme, vol. 2, br. 1, Solin, 2009., str. 205-212; Ante ŠковALJ, "Povijesno značenje jubileja hrvatske kraljice Jelene", u: Crkva u svijetu, Split, 3/1976., str. 210-216; Benedikta Zelić-BučAn, "Najstarije Gospine crkve u Hrvata", u: Crkva u svijetu, Split, 3/1976., str. 247-256; N. BUDAK, Prva stoljeća Hrvatske, str. 34; T. RAUKAR, Hrvatsko srednjovjekovlje, prostor, ljudi, ideje, str. 241-243; F. ŠAnJeK (ur.), Povijest Hrvata, knj. 1, Srednji vijek, str. 94, 155-156. Da s vremenom interes za kraljicu Jelenu ne jenjava pokazuje i Znanstveni kolokvij Helena mater u povodu 120 godina od otkrića crkve i nadgrobnog natpisa hrvatske kraljice Jelene 1898.-2018., održan u Solinu 2018. godine.

24 O Petru Snačiću: N. Budak, Prva stoljeća Hrvatske, str. 48; T. Raukar, Hrvatsko srednjovjekovlje, prostor, ljudi, ideje, str. 58-59; F. ŠANJEK (ur.), Povijest Hrvata, knj. 1, Srednji vijek, str. 185. 
Dijana Korać - Marina Beus - Komemoriranje srednjovjekovnih hrvatskih vladara...

kneza Višeslava (prva polovica 9. st.), u čije je vrijeme došlo do pokrštavanja Hrvata, odnosno posebno značenje u nacionalnoj povijesti zauzima Višeslavova krstionica kao simbol pokrštavanja Hrvata. ${ }^{25}$

Grad Široki Brijeg po jednu ulicu posvetio je knezu Zdeslavu (2,2\%) te kralju Stjepanu Držislavu (2,2\%). Valja kazati kako je knez Zdeslav (878.-879.) dobio jednu ulicu u Hercegovini, dok u Hrvatskoj nije. $\mathrm{Na}$ jačanje nacionalne svijesti zasigurno nisu utjecale činjenice da je Zdeslav bio bizantski kandidat na hrvatsko prijestolje nakon čijega ubojstva na vlast dolazi knez Branimir i nastavlja tradicionalno vezivanje uza Zapad, ali jesu one koje potvrđuju da je riječ o sinu slavnoga kneza Trpimira kojega papa Ivan VIII. u jednome pismu naziva "ljubljenim sinom", što ipak ukazuje na njegove dobre odnose s papinstvom. ${ }^{26} \mathrm{~S}$ druge strane, dok je kralj Stjepan Držislav (969.- o. 997.) komemoriran u šest velikih hrvatskih gradova, u Hercegovini mu je posvećena samo jedna ulica. Dovoljan razlog komemoriranja Stjepana Držislava za jačanje nacionalne svijesti, pa tako i njegova spomena u uličnoj nomenklaturi, jesu činjenice da je bio hrvatski kralj čije je ime sačuvano na dvije kamene ploče s Kapitula kod Knina te vladar koji je prvi nosio naslov "kralja Hrvatske i Dalmacije". Valja reći da je prema pisanju Tome Arhiđakona znakove hrvatske vlasti Držislav dobio od Bizanta što se u hrvatskoj historiografiji osporavalo. ${ }^{27}$

U Posušju, gdje je evidentiran najveći broj hodonima koji nose ime po srednjovjekovnim hrvatskim vladarima, nalazimo i po jednu ulicu posvećenu Ljudevitu Posavskom (2,2\%) te ugarsko-hrvatskom

25 O knezu Višeslavu i tumačenju njegove krstionice u historiografiji: N. BudAK, Prva stoljeća Hrvatske, str. 29-30; T. RAUKAR, Hrvatsko srednjovjekovlje, prostor, ljudi, ideje, str. 24-26. Posve drugačije mišljenje o Višeslavovoj krstionici u novije vrijeme donosi: Nikola Jakšić, "Manipulacija povijesnim spomenicima - primjer Višeslavove krstionice", u: Marijana Marinović (ur.), Povijesno naslijede i nacionalni identiteti. Zbornik, Zagreb, 2006., str. 40-45.

26 Usp. B. Grgin, "Primjer selektivnog pamćenja: hrvatski srednjovjekovni vladari u nazivlju ulica i trgova najvažnijih hrvatskih gradova", str. 289. O knezu Zdeslavu: N. Budak, Prva stoljeća Hrvatske, str. 25-26; T. RAUKAR, Hrvatsko srednjovjekovlje, prostor, ljudi, ideje, str. 31-32, 261; F. ŠAnJEK (ur.), Povijest Hrvata, knj. 1, Srednji vijek, str. 85-86; Neven Budak, "Hrvatska i Bizant u 10. stoljeću", u: Tabula, 12, Pula, 2004., str. 53.

27 O kralju Stjepanu Držislavu: N. Budak, Prva stoljeća Hrvatske, str. 35-36; T. RAUKAR, Hrvatsko srednjovjekovlje, prostor, ljudi, ideje, str. 39-41; F. ŠANJEK (ur.), Povijest Hrvata, knj. 1, Srednji vijek, str. 94-95. O razlozima zašto je Stjepan Držislav dobio krunu od Bizanta više u: N. BudAK, "Hrvatska i Bizant u 10. stoljeću", str. 51-63. 
kralju Matiji Korvinu (2,2\%). Ljudevit Posavski (810.-823.) je u historiografiji predstavljen kao inicijator pobune i hrabar borac protiv franačke vlasti, što je dovoljan razlog za njegovo komemoriranje. ${ }^{28}$ $\mathrm{Na}$ kraju, kako je već spomenuto, u Hercegovini nalazimo i jednu ulicu koja nosi ime kralja Matije Korvina (1458.-1490.) što je jedini slučaj komemoriranja ugarsko-hrvatskoga kralja na ovim prostorima. ${ }^{29}$ Njegov spomen u uličnoj nomenklaturi zasigurno je uvjetovan činjenicom o organiziranju protuturskoga obrambenog sustava te pokretanju vojne krajem 1463. godine nakon čega je organizirao Jajačku i Srebreničku banovinu, kao i njegove pomoći Počitelju u obrani od Turaka. ${ }^{30}$

Usporedbom ovih rezultata sa sličnim istraživanjima provedenim u Republici Hrvatskoj evidentna je velika sličnost. Naime, u Hercegovini su kao i u najvećim hrvatskim gradovima u puno većoj mjeri zastupljeni hrvatski ranosrednjovjekovni vladari - knezovi i kraljevi, među kojima prevladavaju hrvatski kraljevi. Očekivano, na prvome mjestu i u Hercegovini nalazi se kralj Tomislav. Razlika se uočava jedino u slučaju imenovanja ulice kneza Zdeslava, koji nije komemoriran ni u jednom od deset najvećih hrvatskih gradova, a u Hercegovini jedna ulica (u Posušju) nosi njegovo ime. Razlika je također uočena i u slučaju komemoracije ugarsko-hrvatskih vladara, jer u Hercegovini nalazimo ulicu kralja Matije Korvina.

28 O Ljudevitu Posavskom: N. Budak, Prva stoljeća Hrvatske, str. 17-18; F. ŠANJEK (ur.), Povijest Hrvata, knj. 1, Srednji vijek, str. 65-67.

29 Pri tome treba ukazati na činjenicu da su rezultati sličnoga istraživanja u Republici Hrvatskoj pokazali da u najvećim hrvatskim gradovima ne postoji komemoracija nijednoga ugarsko-hrvatskoga kralja u nazivlju ulica i trgova. Iznimke čini kralj Salomon i kraljica Elizabeta, žena Ludovika Velikoga, kći bosanskoga bana Stjepana II. Kotromanića koju komemorira Zadar u nazivu jedne ulice. Grgin ispravno zaključuje da je zasigurno jedan od vrlo važnih razloga i poznata škrinja svetoga Šimuna koja se nalazi u ovome gradu a čiju je izradu naručila ova kraljica. B. GRGIN, "Primjer selektivnog pamćenja: hrvatski srednjovjekovni vladari u nazivlju ulica i trgova najvažnijih hrvatskih gradova", str. 284-285.

30 O Matiji Korvinu više: T. RAukAR, Hrvatsko srednjovjekovlje, prostor, ljudi, ideje, str. 91-95; F. ŠAnJEK (ur.), Povijest Hrvata, knj. 1, Srednji vijek, str. 348357, 383-385; Borislav Grgin, Počeci rasapa. Kralj Matijaš Korvin i srednjovjekovna Hrvatska, Zagreb, 2002.; MLAdEN Tomorad, "Europska politika Matijaša Korvina. Matijaševa vanjska politika prvih godina vladavine (14581464)", u: Kroatologija: časopis za hrvatsku kulturu, Zagreb, 2/2011., str. 176203. U navedenim djelima može se vidjeti pregled literature o Matiji Korvinu. 
Dijana Korać - Marina Beus - Komemoriranje srednjovjekovnih hrvatskih vladara...

\begin{tabular}{|l|l|l|}
\hline Ime vladara & $\begin{array}{l}\text { Broj ulica } \\
\text { i trgova }\end{array}$ & Grad/općina \\
\hline Tomislav & 11 & $\begin{array}{l}\text { Mostar, Posušje, Čitluk (tri ulice), Čapljina } \\
\text { (trg), Široki Brijeg, Stolac, Neum, Prozor- } \\
\text { Rama, Grude }\end{array}$ \\
\hline Domagoj & 6 & $\begin{array}{l}\text { Mostar, Posušje, Čapljina, Široki Brijeg, } \\
\text { Stolac, Neum }\end{array}$ \\
\hline Petar Krešimir IV. & 4 & Mostar, Posušje, Čapljina, Široki Brijeg \\
\hline Zvonimir & 4 & Mostar, Posušje, Čapljina, Široki Brijeg \\
\hline Mislav & 3 & Mostar, Posušje, Široki Brijeg \\
\hline Trpimir & 3 & Mostar, Posušje, Široki Brijeg \\
\hline Branimir & 3 & Mostar, Posušje, Široki Brijeg \\
\hline Jelena & 3 & Mostar, Posušje, Široki Brijeg \\
\hline Petar Svačić & 2 & Posušje, Široki Brijeg \\
\hline Višeslav & 2 & Mostar, Posušje \\
\hline Zdeslav & 1 & Široki Brijeg \\
\hline Držislav & 1 & Široki Brijeg \\
\hline Ljudevit Posavski & 1 & Posušje \\
\hline Matija Korvin & 1 & Posušje \\
\hline
\end{tabular}

Tabela 2. Učestalost pojavljivanja pojedinih vladara po gradovima i općinama 


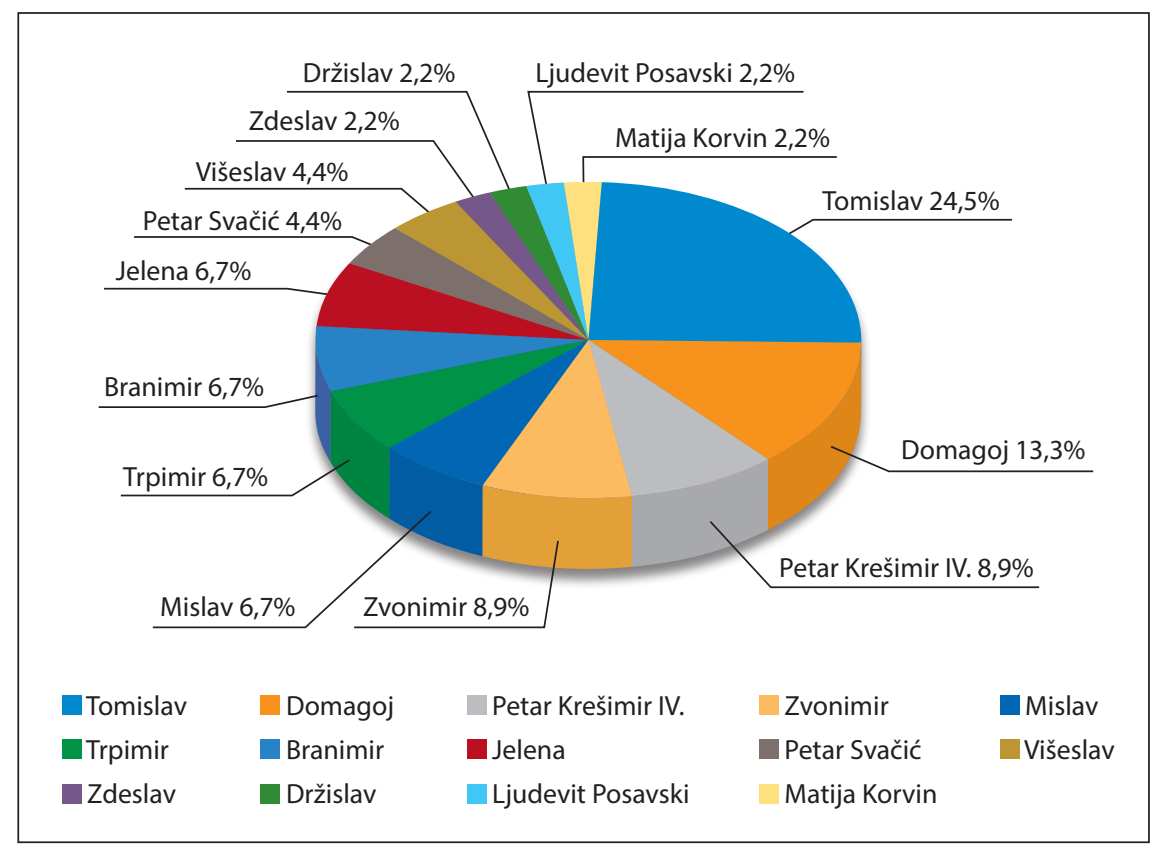

Grafikon 2. Učestalost pojavljivanja pojedinih vladara u hodonimima Hercegovine

\section{Zaključak}

Analiza uličnoga nazivlja u hercegovačkim županijama pokazala je kako su srednjovjekovni hrvatski vladari zastupljeni u gradovima i općinama s većinski hrvatskim stanovništvom, a ovdje prikazana analiza jednoga segmenta uličnoga nazivlja svakako upućuje na jačanje kolektivnoga identiteta hrvatskoga naroda na ovome prostoru ali i na njegovo selektivno sjećanje. Hrvatski vladari, komemorirani u uličnoj onomastici, upućuju na hrvatsku samostalnost i neovisnost, a bitan indikator njihove važnosti, prema mišljenju službene vlasti, jest i činjenica da je većina ulica koje nose njihova imena smještena u centru ili oko gradskoga centra. Prema nama dostupnoj građi u ranijem socijalističkom sustavu nije bilo ulica koje su nosile imena hrvatskih srednjovjekovnih vladara, čak ni onih koji su i u tadašnjem državnom sustavu bili popularni kao primjerice kralj Tomislav. Budući da se radi o dva posve oprječna državna i politička okvira, recepcija hrvatskih narodnih vladara u socijalističkoj Jugoslaviji bila je posve drugačija od one kakva je predočena od 90-ih godina 20. stoljeća, prije svega u službenoj udžbeničkoj literaturi. Stoga su promjene vlasti 90-ih godina prošloga stoljeća i na ovome prostoru donijele, 
između ostaloga, izmjene i u uličnoj nomenklaturi. Kako je riječ o prostoru s većinski hrvatskim stanovništvom te činjenici da lokalnu vlast obnašaju pripadnici hrvatskih nacionalnih stranaka, isticana su nacionalna obilježja pa slijedom toga jedanaest ranosrednjovjekovnih hrvatskih knezova i kraljeva, kao i jedan ugarsko-hrvatski kralj, dobili su svoje mjesto u uličnoj nomenklaturi Hercegovine. Usporedbom ovih rezultata sa sličnim istraživanjima provedenim u Republici Hrvatskoj evidentna je velika sličnost. Naime, u hercegovačkim su hodonimima kao i u najvećim hrvatskim gradovima u puno većoj mjeri zastupljeni hrvatski ranosrednjovjekovni vladari - knezovi i kraljevi, među kojima pak prevladavaju hrvatski kraljevi. Očekivano, na prvome mjestu i u Hercegovini nalazi se kralj Tomislav. Razlika se uočava u slučaju imenovanja ulice kneza Zdeslava, koji nije komemoriran ni u jednom od deset najvećih hrvatskih gradova, a u Hercegovini jedna ulica (u Posušju) nosi njegovo ime. Razlika je također evidentna i u slučaju komemoracije ugarsko-hrvatskih vladara. Dok $\mathrm{u}$ deset najvećih hrvatskih gradova nije komemoriran nijedan vladar Ugarsko-Hrvatskoga Kraljevstva, u hercegovačkim hodonimima nalazimo jednoga od njih - Matiju Korvina. Kako se vladari stranoga podrijetla ne uklapaju u ovakvu koncepciju razmišljanja i imenovanja hodonima, što je pokazala slična analiza ulične nomenklature u najvećim hrvatskim gradovima, pojašnjenje "izoliranom" slučaju komemoracije Matije Korvina na prostoru Hercegovine zasigurno leži u povijesnim činjenicama koje se odnose na njegov protuturski obrambeni sustav i njegovu ulogu u obrani ovih prostora od Osmanlija. 
DiJana Korać

University of Mostar

Faculty of Humanities and Social Sciences

E-mail: dijana.korac@ff.sum.ba
Short communication

Received: 3 May 2020

Accepted: 10 June 2020

Marina Beus

University of Mostar

Faculty of Humanities and Social Sciences

E-mail: marina.beus@ff.sum.ba

\section{Commemoration of medieval Croatian rulers in the odonyms of Herzegovina}

\section{Summary}

The article analyzes presence of medieval Croatian rulers in the names of streets and squares in two Herzegovinian cantons (Herzegovina-Neretva and West Herzegovina). The analysis of the street names showed that Croatian medieval rulers were represented in the cities and municipalities with Croatian majority population. Comparing the obtained data to results of similar research in the Republic of Croatia great similarities can be noticed. Namely, Croatian early medieval rulers - dukes and kings (11 of them were commemorated in total), among whom Croatian kings dominated, were represented to a much greater extent in both Herzegovinian odonyms and largest Croatian cities. As it is expected, King Tomislav is on the first place in Herzegovina. Difference can be noticed in the case of naming the street after Duke Zdeslav, who has not been commemorated in any of the ten largest Croatian cities and one street in Herzegovina (in Posusje) was named after him. The difference is also evident in commemoration of the Hungarian-Croatian rulers. None of the rulers of the Kingdom of Hungary and Croatia has been commemorated in the ten largest Croatian cities, while there is one in the Herzegovinian odonyms - Matija Korvin.

Keywords: medieval Croatian rulers; Herzegovina; odonyms; streets; squares. 